PRZEGLĄD NAUK HISTORYCZNYCH 2017, R. XVI, NR 1

http://dx.doi.org/10.18778/1644-857X.16.01.07

ELEONORA JEDLIŃSKA

UNIWERSYTET ŁÓDZKI*

\title{
Obraz jest świadectwem niewyobrażalnego Ekspresjonizm abstrakcyjny i Zaglada (Mark Rothko, Barnett Newman, Frank Stella)
}

Ważne, by pamiętać, że „abstrakcyjny” nie oznacza pusty $w$ treści; oznacza, że zwiąek między treścia a jej interpretacja nie jest konkretny.

Christopher Rothko

Streszczenie. Wydarzenia rozgrywające się w Europie w okresie panowania ideologii faszystowskiej wywarły znaczacy wpływ na malarstwo artystów amerykańskich związanych $z$ ekspresjonizmem abstrakcyjnym. Nazwa „ekspresjonizm abstrakcyjny”, nieprecyzyjna i nieco mylacca, pozostała pojęciem trwale obecnym w terminologii naukowej historii sztuki. Rozważając jednak tę sztukę z perspektywy wydarzeń, które miały miejsce w Europie między 1933 a 1945 r., posiłkujac się znaczacymi tytułami prac i kontekstem ich powstania - Marka Rothko ponumerowane, szare, brunatne i czarne murale do Seagram Building na Manhattanie $z$ końca lat pięćdziesiątych, czarne i brunatne obrazy do kaplicy w Houston powstałe w latach siedemdziesiatych, Barnetta Newmana 14 obrazów The Stations of the Cross: Lema Sabachthani, Franka Stelli minimalistyczny obraz zatytułowany Arbeit macht frei (1958), The Polish Village Series, seria 24 czarnych obrazów powstałych w młodzieńczym okresie twórczości artysty - sięgając do wypowiedzi tych artystów, ich biografii, winniśmy tę sztukę rozpatrywać jako sztukę historyczną.

Trzej przedstawiciele tego nurtu, Barnett Newman, Mark Rothko, Frank Stella, którym poświęcony jest niniejszy artykuł, reprezentuja malarstwo pozornie pozbawione odniesień formalnych, próbuja poprzez nie wyrazić niewyobrażalne, niejako zmuszając umysł do wyobrażenia sobie, czym było piekło Auschwitz.

* Wydział Filozoficzno-Historyczny, Katedra Historii Sztuki, e-mail: eleonora. jedlinska@gmail.com; eleonora.jedlinska@uni.lodz.pl. 
Słowa kluczowe: malarstwo, ekspresjonizm amerykański, abstrakcja, filozofia, świadectwo prawdy, Mark Rothko, Barnett Newman, Frank Stella, Holocaust.

$\mathrm{J}$ akkolwiek niemożliwe jest precyzyjne określenie dnia narodzin ekspresjonizmu abstrakcyjnego ${ }^{1}$ (szkoły nowojorskiej), otwarcie w 1942 r. przez Peggy Guggenheim galerii Art of This Century należy postrzegać jako jedna $z$ ważniejszych dat w historii Szkoły. Gdy w Europie wybuchła wojna, Peggy Gugenheim, bratanica słynnego kolekcjonera dzieł Wassila Kandinskiego, Solomona R. Guggenheima, musiała, jako Żydówka, ratować się ucieczką ze Starego Kontynentu. „Wojna, jak to przewidzieli surrealiści, wydarła $z$ nas utajone przerażenie, ponieważ przerażenie może istnieć dopóty, dopóki pozostaja nie znane siły tragedii. Teraz wiemy, jak wyglada przerażenie. [...] Przerażenie stało się w istocie równie realne jak życie. Teraz jesteśmy raczej $\mathrm{w}$ tragicznej, a nie przerażającej sytuacji" ${ }^{2}$ - to fragment eseju Barnetta Newmana napisanego w 1945 r., wskazujący, jak ważną kwestia dla artystów amerykańskich, którzy nie doświadczyli w sposób bezpośredni wydarzeń II wojny światowej i Zagłady, była ich konkretna reakcja na tragedię i konsekwencje wojny.

Historia Europy lat 1933-1945 miała znaczacy wpływ na malarstwo artystów amerykańskich, których twórczość historia sztuki właczyła w obszary ekspresjonizmu abstrakcyjnego (szkoła nowojorska, ekspresjonizm amerykański) lat czterdziestych, pięćdziesiatych i sześćdziesiątych XX w. Pojęcie „ekspresjonizm abstrakcyjny”, jakkolwiek nieścisłe i w pewnym stopniu mylące, stało się terminem trwale obecnym w terminologii naukowej dziedziny. Stał się zatem, jak zaznacza Charles Harrison, „względnie neutralny”3.

Trzej przedstawiciele tego nurtu (Mark Rothko, Barnett Newman, Frank Stella), których wybrane dzieła odnoszą się do katastrofy

1 Terminu „ekspresjonizm abstrakcyjny” (abstract expresionisme) użył po raz pierwszy w odniesieniu do malarstwa Wassila Kandinskiego Alfred Barr w 1929 r., spopularyzował go zaś Robert Myron Coates w 1946 r.

2 B. Newman, The New Sense of Fate, poczatkowo niepublikowany esej $z$ roku 1945, który został zacytowany przez Thomasa Hessa w artykule $z 1951 \mathrm{r}$. pt. What Abstract Art Means to Me, powstałym na podstawie rozmowy Hessa z Willem de Kooningiem 7 II 1951 r. Rozmowa krytyka i artysty stanowiła część sympozjum zorganizowanego przez Museum of Modern Art w Nowym Jorku, http:/ /www.warholstars.org/abstract-expressionism/timeline/abstractexpres sionism51.html (dostęp: 17 IV 2017 r.).

${ }^{3}$ Ch. Harrison, Ekspresjonizm abstrakcyjny, przekł. H. Andrzejewska, [w:] Kierunki i tendencje sztuki nowoczesnej, Warszawa 1980, s. 267. 
Zagłady, tworzyli dzieła rozpoznawane jako abstrakcyjne i związani byli $z$ nurtem ekspresjonizmu abstrakcyjnego. Świadectwo Zagłady dane przez obraz pozbawiony (pozornie) odniesień formalnych jest próbą, dążeniem do wyrażenia niewyobrażalnego, niejako zmuszeniem umysłu do wyobrażenia sobie, czym było piekło Auschwitz. A przecież zmuszając umysł do wyobrażenia sobie Zagłady, nie odwołujemy się do niewyobrażalnego. Obraz abstrakcyjny, który w swej treści, formie, przesłaniu filozoficznym odnosi się do śmierci sześciu milionów Żydów, nie mówi o abstrakcji, nie jest odwołaniem do niewyobrażalnego. Seria Czarnych obrazów Franka Stelli, The Stations of the Cross: Lema Sabachthani Barnetta Newmana $z$ lat 1970-1974, Czarne obrazy Marka Rothki sa dziełami, przez które malarze usiłuja obrazować eksterminację, ich abstrakcyjna forma, surowa, ciemna tonacja barwna, powaga, milczenie, które ewokuja, wreszcie żmudny proces ich powstawania, uwznioślaja i sakralizuja ofiary Holocaustu. Okrucieństwom wojny obrazy (obrazy abstrakcyjne) przywracają widzialność, ujawniają coś, co ukrywano za pojęciami takimi jak nieprzedstawialność czy niewyobrażalność. Wybrani - w ramach prezentowanego tekstu - twórcy podjęli trud wyobrażenia historii, okazali się - jak pisała Doreet LeVitte Harten - „prawdziwymi historykami, nadali bowiem kształt milczeniu" ${ }^{\prime}$. Artyści stanowiący treść tego artykułu, których wybrane dzieła odnoszą się do Holocaustu, posługując się abstrakcyjna, powściagliwą, surowa forma, powołali dzieła wyrażające najwyższy stan godności okazywanej śmierci, $z$ jaka spotykamy się w kulturze zachodniej. Żaden $z$ przywołanych $\mathrm{w}$ tym tekście malarzy nie doświadczył bezpośrednio Zagłady, żaden $z$ nich „nie przeszedł przez to swoiste piekło", jednakże wrażenie, jakie na nich wywarła wiedza o koszmarze, jakiego doświadczyli europejscy Żydzi, jest dobrze udokumentowana. Twórczość tych artystów można rozważać, nie nawiązując do Holocaustu, traktując ją w kategoriach czystej abstrakcji, pozbawionych odniesień emocjonalnych i czerpać $z$ niej przyjemności estetyczne czy religijne. Rozważajac jednak tę sztukę $z$ perspektywy wydarzeń, które miały miejsce w Europie między 1933 a 1945 r., posiłkując się znaczacymi tytułami prac i kontekstem ich powstania - Marka Rothki ponumerowane, szare, brunatne i czarne murale do Seagram Building na Manhattanie z końca lat pięćdziesiątych, czarne i brunatne obrazy do kaplicy

${ }^{4}$ D. LeVitte Harten, Przekładanie bólu na kolor, [w:] Gdzie jest brat Twój, Abel?, katalog wystawy Galerii Zachęta w Warszawie, Warszawa 1995, s. 16. 
w Houston powstałe w latach siedemdziesiatych, Barnetta Newmana 14 obrazów The Stations of the Cross: Lema Sabachthani, Franka Stelli minimalistyczny obraz zatytułowany Arbeit macht frei (1958), The Polish Village Series, seria 24 czarnych obrazów powstałych w młodzieńczym okresie twórczości artysty - sięgając do wypowiedzi tych artystów, ich biografii, winniśmy tę sztukę rozpatrywać jako sztukę historyczną. Twórcy ci nadali kształt milczeniu.

$$
* * *
$$

Mark Rothko (Marcus Rothkowitz) urodził się w 1903 r. w Dźwińsku (Dvinsk) w Rosji (obecnie Daugavpils mieści się w granicach Łotwy), w żydowskiej rodzinie. W tamtych latach miasto zamieszkiwało 90 tys. ludzi, z których połowę stanowili Żydzi. Ojciec Jakub Rothkowitz prowadził w aptekę, matka Katarzyna zajmowała się domem. Mając pięć lat, Marcus, najmłodszy z czworga starszego rodzeństwa, dla którego Jakub wybrał wychowanie świeckie, jako jedyny rozpoczał naukę w miejscowym chederze, gdzie uczył się czytania, modlitwy, tłumaczenia tekstów hebrajskich i prawa talmudycznego. Jako jedyny zatem otrzymał formalne religijne wykształcenie. W domu rodzinnym, wedle wspomnień siostry artysty Soni, znajdowała się biblioteka składająca się z kilkuset tomów, mówiono w jidysz, po hebrajsku i rosyjsku. Wyjechawszy w 1913 r. z Dźwińska jako dziesięcioletni chłopiec, nigdy tam już nie powrócił, jego związki $z$ tym miejscem zostały zerwane.

Studiowanie religijnych tekstów $z$ dzieciństwa wykształciło $\mathrm{u}$ Rothki nawyk interpretowania rzeczywistości w kategoriach duchowych; kultywował potrzebę transcendencji, oddając się lekturze europejskich powieści, dramatów i tekstów filozoficznych. Czytał Ajschylosa, Williama Szekspira, Fiodora Dostojewskiego, Stéphane'a Mallarmégo, Arthura Rimbauda, Sørena Kierkegaarda, Fryderyka Nietzschego. Świadomość oderwania od własnych korzeni, utraty poczucia przynależności do wspólnoty żydowskiej była refleksem historycznych zmian, które zdeterminowały tragiczny los świata jego młodości. Dwie wojny światowe w ciagu zaledwie pół wie$\mathrm{ku}$, narastające nastroje antysemickie opanowujące Rosję, których eskalacja przypadła na 1905 rok, decyzja ojca, by rodzina opuściła Europe, spowodowały oderwanie od rodzinnych stron, którego nie sposób było scalić. „Holocaust pogłębił jego [Rothki - przyp. E.J.] 
poczucie tragedii"5. Wzmagające się poczucie wyobcowania, pesymi$z m u$ rodzącego coraz głębszą depresję umacniały wieści $z$ wojennej Europy i kolejne kryzysy obejmujące Stany Zjednoczone po drugiej wojnie światowej (okres maccartyzmu, wojen w Korei i Wietnamie). Mimo zewnętrznego odcięcia się od świata, $z$ którego się wywodził, zdaniem przyjaciół, na zawsze w jakimś sensie do niego przynależał. „Publicznie Rothko nie wypowiadał się na temat swego dzieciństwa w Rosji - pisze Marek Bartelik. - W sferze osobistej ta część świata była dla niego nie tyle kraina melancholii $z$ opowiadań Szolema Alejchema, ile knutów Kozaków, jaskrawego symbolu nieszczęścia i ucisku Żydów w strefie osiedlenia, która to krainę konstruował z osobistych wspomnień, przekazów historycznych...”.

Szczególną rolę w życiu Rothki odegrał egzystencjalizm Nietzscheański, zawarty w Narodzinach tragedii $z$ ducha muzyki (1872); później wydanych jako Narodziny tragedii albo Grecy i pesymizm. Artysta zainteresowany był przede wszystkim rozważaniami niemieckiego filozofa dotyczącymi możliwości intelektualnego współistnienia aspektu przeciwieństw: apollińskiego i dionizyjskiego, przedstawieniowości i abstrakcji oraz w jaki sposób można wykorzystać je w sztuce. „Nie uważam, by kiedykolwiek istniało pytanie, czy być abstrakcyjnym, czy figuratywnym - pisal. - W istocie to kwestia zakończenia tej ciszy i samotności, przełamania i wyciagnięcia znowu ramion"7. Rothko podziwiajac Nietzschego, przeciwstawiał się wykorzystywaniu jego pojęcia Übermenscha do ideologii niemieckiego nacjonalizmu i rasizmu. Przeciwstawiając się podejmowaniu w sztuce problemów osobistych, był żarliwym zwolennikiem wyrażania emocji w skrajnie powściagliwej formie. Gdy mówił o sztuce - jednakże - konstatował takie jej własności, które winny być jej przesłaniem. Przede wszystkim podkreślał znaczenie skoncentrowania uwagi na problemie śmierci: „napomknienie o śmiertelności. [...] Sztuka tragiczna, sztuka romantyczna etc. zajmuje się świadomością śmierci [...]. Nadzieja - pisał. - Dziesięć procent, by uczynić tragiczna koncepcję bardziej znośna"s. W powstałych

${ }^{5}$ M. Bartelik, Na zewnatrz widzenia. Lekcje Marca Rothki, [w:] Mark Rothko. Obrazy $z$ National Gallery of Art $w$ Waszyngtonie, red. M. Bartelik, katalog wystawy Muzeum Narodowe w Warszawie, Warszawa 2013, s. 50.

6 D. Ashton, About Rothko, New York 1996 (wyd. 1 1983), s. 7.

7 The Romantics Were Prompted, 1947, [w:] Mark Rothko. Writings on Art, ed. M. Lopéz-Remiro, New Haven-London 2006, s. 58-59.

8 Address to Pratt Institute, November 1958, [w:] ibidem, s. 125-126. 
w latach pięćdziesiątych notatkach do nieukończonego eseju poświęconego Nietzschemu Rothko sformułował własne przekonania odnoszace się do etycznego wymiaru sztuki. Przypisując swoim obrazom rolę medium, przekazującego egzystencjalne treści wcielające tragiczna formułę doświadczania rzeczywistości, widział swą sztukę jako samą istotę możliwości poznawczych człowieka i w takich kategoriach traktował właściwy kontekst twórczości artystycznej: „malarstwo nie jest obrazem doświadczenia - pisał - jest samym doświadczeniem" .

Najsławniejsze obrazy Marka Rothki, poprzedzone monumentalnym malarstwem figuratywnym oraz obrazami tzw. okresu mitologicznego, powstały po roku 1949. Zanim jednakże przejdziemy do ich omawiania, chciałabym zatrzymać się przy dwóch obrazach „mitologicznych”, jako pośrednio odnoszacych się do tragedii Holocaustu. Dnia 5 stycznia 1942 r., za sprawa marszanda i właściciela galerii Kootza Samuela, na Herald Square w Nowym Jorku, słynnym centrum handlowym, wystawiono dwa obrazy Rothki: Edypa z 1940 r. i Antygonę z 1941 r. Tematyką obrazy te nawiąywały do tragedii greckiej, należały do cyklu prac artysty, które - pod względem stylu i motywu - całkowicie różniły się od wcześniejszych, bardziej monumentalnych przedstawień figuratywnych. Ta seria, namalowana między 1940 a 1943 r., związana jest ze szczególnym okresem życia artysty. Ich powstanie zbiegło się w czasie ze wstrząsającymi wiadomościami $z$ frontów drugiej wojny światowej, prześladowaniem Żydów w Europie oraz przystąpieniem Stanów Zjednoczonych do wojny.

Zatrzymajmy się przy opisie dzieł: w obrazie zatytułowanym Edyp (1940) rozczłonkowane, zdezintegrowane ciała i wnętrzności jednocześnie wnikają w siebie i się rozdzierają. Profile, podobne do greckich masek, zdają się być echem kubizmu Pabla Picassa, którego Rothko nie cenił, uważając go za artystę zbyt skoncentrowanego na stylu i formie. Postaci w obrazie Antygona (1941) sa uszeregowane, ich rozczłonkowane ciała tworza niezsynchronizowana, bezładną antycałość. W górnym rzędzie widoczne są cztery męskie głowy połączone profilami zwróconymi w przeciwnych kierunkach. $Z$ prawej i lewej strony zauważalne sa zarysy ramion. Namalowane poniżej czterech głów duże, morficzne kształty przypominają nagie kobiece torsy. W najniższym pasie kompozycji, na niebieskim tle, umieszczone są niby-zwierzęce formy - zniekształcone, wynaturzone, nawiązu-

\footnotetext{
9 A.C. Chave, Mark Rothko. Subjects in Abstraction, New Haven 1989, s. 172.
} 
jące do antycznego reliefu. Umieszczone sa pod czymś, co kojarzono ze stołem ofiarnym czy ołtarzem. Temat obrazu odwołuje się do Orestei Ajschylosa - historii o morderstwie, samobójstwie i spełnieniu się przepowiedni: „rytuały i tabu związane ze śmiercią prowokuja pytania o znaczenie wierności, zaufania, zdrady i przemocy - pisze Norman L. Kleeblatt - obnażając również nadużycia władzy"10.

U Marka Rothki zwrot ku mitologii oznaczał wkroczenie na drogę, która zaprowadziła go do Carla Gustava Junga i jego teorii zbiorowej podświadomości poza czasem i przestrzenią. Czerpał z mitów greckich, chrześcijańskich, egipskich, szczególne znaczenie w jego życiu jednakże miała mitologia żydowska (Obrzędy Lilith z 1945 r., obraz pt. Dwaj Żydzi z lat 1924-1925), wspierał swą wrażliwość naukami wywiedzionymi $z$ pism teologii judajskiej, tylko one - uważał - moga w pełni wyrazić emocje zwiazane $z$ okropnościami wojny. „Taki synkretyzm znosił kwestię żydostwa artysty w znaczeniu przynależności społecznej - pisze Pamel A. Pappas - niemniej wskazywał wprost na tragiczne wydarzenia współczesne"11. Obecność w jego sztuce motywów z Orestei Ajschylosa i biblijnej Księgi Wyjścia: ofiara Ifigenii i Izaaka, ofiara Chrystusa oraz los Żydów na wygnaniu - ukazuja nam, jak równomiernie artysta traktował owe trzy główne mity. Odwołanie do tak precyzyjnie określonych źródeł umożliwiło Rothce tworzenie dzieł-poematów-modlitw za złożone ofiar, wyrażonych w wysublimowanej estetycznie formie, bliskiej estetyce moralnej, wywiedzionej z myśli Nietzschego i uniknięcie zarazem „romantycznej i zmysłowej estetyzacji”12. James Breslin, biograf artysty, na podstawie analizy szkicownika Rothki $z$ ok. 1940 r. postawił tezę, że zawarte w nim „wizualne skojarzenia moga stanowić podstawę, by wiązać estetykę moralna reprezentowana przez Rothko $z$ bliska psychologii Junga charakterystyka dwuznaczności obrazu - bądź podlegająca wolnym skojarzeniom naturze serii mitologicznej - oraz że w konsekwencji zostanie ona przekształcona w dwuznaczna przestrzeń jego obrazów z końca lat czterdziestych i pięćdziesiątych - obrazów barwnych płaszczyzn" ${ }^{13}$.

${ }^{10}$ N.L. Kle eblatt, Tragedia u Macy'ego. Rothko i mit, przekł. M. Lavergne, [w:] Mark Rothko. Obrazy..., s. 117.

11 P.A. Pappas, Mark Rothko and the Politics of Jewish Identity, 1939-1945, [rozprawa doktorska, University of Southern California], Los Angeles 1997. Podaje za: N.L. Kle eblatt, op. cit., s. 119.

${ }^{12}$ Z.A. Maisels, Depiction and Interpretation: The Influence of the Holocaust on the Visual Arts, Oxford 1993, s. 45.

13 J.E.B. Breslin, Mark Rothko. A Biography, Chicago 1989, s. 161. 
Obrazy okresu mitologicznego w istocie możemy rozpatrywać jako prowadzące ku malarstwu, które stało się idiomem Marka Rothki.

Niemal sześć lat trwał pro-

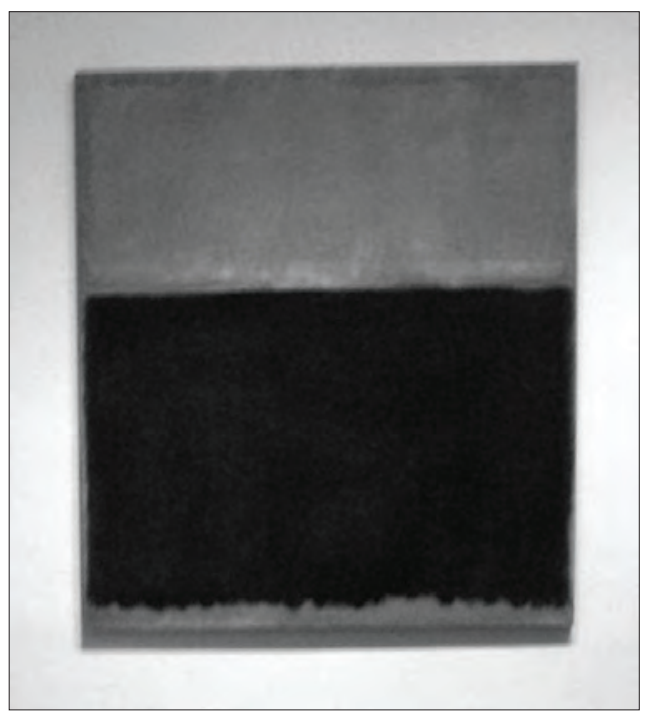

1. Mark Rothko, Bez tytułu, 1953 r., olej na płótnie, National Gallery Waszyngton. Fot. E. Jedlińska ces, którego wynikiem pozostało malarstwo barwnych płaszczyzn albo zasłon, $z$ upływem czasu stających się coraz ciemniejszymi, aż po głęboką wibrująca czerń ostatnich, tworzonych tuż przed samobójczą śmiercią (czarne obrazy w kaplicy Rothki w Houston). Najsławniejsze obrazy Rothki, które zaczął malować po 1949 r., sa dziełami abstrakcyjnymi. Ich rozedrgane płaszczyzny, esencjonalność barw radykalna i poetycka jest wyjątkowym portretem ludzkiego losu, sporządzonym przez artystę w XX w. Malując te dzieła, skupiony był na „wyrażaniu podstawowych ludzkich emocji - jak mówił - tragedii, ekstazy, nieszczęścia" ${ }^{14}$, czynił to $z$ pomoca malarstwa abstrakcyjnego, tworząc rozległe płaszczyzny koloru, wyrażające emocjonalną i dramatyczną siłę. Obrazy Rothki powstałe po 1949 r. znamionuja emanujący $z$ nich przezroczysty blask, jak gdyby zamknięte w nich niezastygłe światło. Ich religijny wymiar obecny jest w otaczającej je miękkiej aureoli. Rothko zachwycał się możliwością uchwycenia jednolitości światła w obrazie, światła mogacego skupić w sobie jako jedność masę cienia i światła właśnie tak, by podporządkować owej masie wszystkie pozostałe barwy jednemu, jedynemu tonowi. Ta jednolitość światła, tak charakterystyczna dla malarstwa Rothki, służyła mu do przekazania najgłębszych uczuć. Cechą łącząca jego obrazy jest niespotykany efekt żarzącego się światła wyrażającego - pod pozornie czysta abstrakcja płaszczyzn koloru - żar uczucia. Artysta chciał, by jego obrazy oglądano $z$ bliska (zalecał 18 do $45 \mathrm{~cm}$,

${ }^{14}$ M. Rothko, The Artist's Reality. Philosophies of Art, ed. C. Rothko, New Haven-London 2004, s. 108. 
zamiast 6 do $12 \mathrm{~m}$ ); wielkie, pochłaniające widza płótna miały przywracać poczucie bliskości.

„Obrazy Rothko sa dziełami skomponowanymi absolutnie, przemyślanymi i poddanymi głębokiej analizie; nic w nich nie ma spontanicznego - pisze Christopher Rothko, syn artysty. - Usiłują być konkretne, jak tylko możliwe w przypadku tematów, które często stoją w sprzeczności $z$ konkretem. Sa skonstruowane w niezaprzeczalnie celowy sposób" ${ }^{15}$. Wewnętrzna harmonia i równowaga każdego obrazu osiagnięta została przez obecność organizującej te dzieła pionowej konstrukcji: barwy, formy układane warstwami jedne na drugich, tworzace w rezultacie „z gruntu muzyczne zestawienie" o sile wywiedzionej $z$ ducha romantyzmu europejskiego. Robert Rosenblum, pisząc o malarstwie Rothki i Barnetta Newmana, zauważył: „dążenie romantyków do sztuki, która miałaby przekazać odczucia niezgłębionej tajemnicy, czasami żywiołowo powracało do życia, jak w przypadku Marka Rothko i Barnetta Newmana, $z$ wyraźnym podtekstem religijnym"16. Obcując $z$ tymi obrazami, odczuwamy dominujacy nad nimi niczym nieskrępowany gest, emanujacy tak samo ze sposobu nanoszenia farby, jak i z sugestywnego dążenia koloru ku krawędziom, jakby ów kolor miał rozchodzić się gdzieś dalej, poza granice obrazu. Napotykamy tu szczególne napięcie zachodzące między klasycznie zakomponowana formą dzieła a usilnym dążeniem do porozumienia się $z$ widzem na poziomie emocji, będących doświadczeniem indywidualnym, wręcz intymnym. Akcent położony na to, co emocjonalne, na osobiste doświadczenie jako droga prowadząca do prawdy, jest - jak pamiętamy - istota doświadczenia romantyzmu. I jeszcze jedna dojmujacca cecha obrazów Rothki okresu tzw. dojrzałego: cisza, która wcale nie jest pustką - jest wypełniona brzemieniem czasu przeszłego i czasu przyszłego, wypełnia cała przestrzeń obrazów i przekracza ich ramy. Poczucie przestrzeni, które Rothko buduje w swych obrazach, odgrywa rolę służebną wobec widza, wciagając go w swe głębie i jednocześnie ofiarowujac mu ich zgłębienie.

Abstrakcja obrazów Rothki, ich ascetyczna powściagliwość, klarowność formy i treści umożliwiające połaczenie idei ze sztuka, oczyszczona $z$ anegdoty sama idea właśnie pozwoliła artyście

15 Ch. Rothko, Mark Rothko i muzyka, przekł. Maja Lavergne, [w:] Mark Rothko. Obrazy..., s. 146.

${ }^{16}$ R. Ros e n blu m, Modern Painting and the Northern Romantic Tradition. Friedrich to Rothko, New York 1975, s. 197. 
uchwycić to, co - pozornie - wydaje się niewyrażalne: ból, cierpienie, żal, tragedię, niemożność trwania po Holocauście. Abstrakcja najtrafniej ujmuje konkretność ludzkiego doświadczenia, której każda próba opisania skazana jest na porażkę. „Jest empiryczna: zmysłowa i duchowa jednocześnie"17.

$$
* * *
$$

W czasie, który nastąpił po Zagładzie, sztuka nie potrafiła znaleźć języka i obrazu, które mogłyby mówić o cierpieniu i bólu pozbawionych znaczenia. Doświadczenie Auschwitz, ten rodzaj cierpienia bez symbolu, misji, aktu wyniesienia nie mogło już odwoływać się do tradycyjnego wyobrażenia cierpienia Jezusa Ukrzyżowanego jako paradygmatycznego wizerunku bólu w sztukach plastycznych. Artyści „pozbawieni” ikonografii Holocaustu stanęli w obliczu pustki dawnych znaków, które niewprawnie użyte mogłyby - nie uragając pamięci ofiar Auschwitz - ewokować tandetną dosłownością, ilustracyjnością bądź, pragnąc ukoić ból, wyposażyć je w cechy postrzegane jako estetyczne, ale kłamliwe, tworzyli zatem sztukę nieprawdy. Przedstawiając koszmar, artyści, chcąc dać świadectwo własnych przeżyć, tworzyli dokument, często pozbawiony decorum, rażący dosłownością, która nie mogła zmienić widza ani go poruszyć, bywało, że nie potrafili przejść ze świata Auschwitz do świata sztuki. Czynili tak „nie dlatego, że byli złymi artystami, lecz dlatego, iż stanęli wobec wydarzenia, którego nikt przed nimi nie próbował zobrazować. Zmagali się z nagimi faktami, pozbawionymi ikonografii" 18 .

W roku 1958 Mark Rothko otrzymał intratne zlecenie wykonania serii wielkoformatowych obrazów-murali do wnętrz ekskluzywnej restauracji Four Seasons (zaprojektowanej przez Philipa Johnsona), mieszczącej się w luksusowym biurowcu na Manhattanie (zaprojektowanym przez Miesa van der Rohego). Zleceniodawca był Joseph E. Seagram, potentat kanadyjskiej firmy produkującej whisky ${ }^{19}$.

17 Ch. Rothko, op. cit., s. 153.

18 D. LeVitte Harten, op. cit., s. 14.

19 Historia związana $z$ Seagram Building (1954-1958) na Manhattanie, dziełem Mies van der Rohego oraz muralami Rothki do restauracji Four Seasons, została szczegółowo opisana [w:] B.H. (B.H.) Friedman, The Most Expensive Restaurant Ever Built, „Evergreen Review” 1959, No. 10, http://www.evergreenreview.com/ 120/friedman.html (dostęp: 12 III 2016 r.). Por. także E. Stoller, F. Schulze, The Seagram Building, Princeton 1999. 
Restauracja miała być najbardziej zbytkownym miejscem w Nowym Jorku, którego charakter i klimat kształtowały znajdujące się w jej wnętrzu dzieła sztuki najwybitniejszych artystów nowoczesnych $^{20}$. Seria obrazów Rothki, wykonanych do wnętrza Four Seasons, uderza ograniczona gamą barw oscylujących między brunatną czerwienia przechodzacca w brąz ku czerni, gdyż artysta ten stosował nie więcej niż dwa kolory na jednym płótnie. Podczas dwóch lat pracy nad muralami do Seagram Building Rothko wykonał 40 obrazów, ustawicznie zestawiając, mieszając płótna pierwszej i drugiej serii, poprawiając, zmieniając decyzje, które obrazy ostatecznie będa przeznaczone do restauracji. Do wnętrza Four Seasons zostało przeznaczonych siedem płócien. W styczniu 1961 r., podczas wystawy w Museum of Modern Art w Nowym Jorku, pokazano obrazy tego cyklu, według numeracji sporządzonej przez Marka Rothkę, wszystkie datowane sa na 1959 r.: Mural. Section 2, Mural. Section 3, Mural. Section 4, Mural. Section 5 oraz Mural. Section 7. Dzieła nr 1 i 6 nie zostały zidentyfikowane. Obrazy nigdy nie znalazły się w Four Seasons.

Szkic do muralu nr 4 z 1958 r. $(265,8 \mathrm{~cm} \times 379,4 \mathrm{~cm})$, obecnie znajdujący się w muzeum Kawamura Memorial w Japonii, namalowany został farbami olejnymi na poziomo ustawionym płótnie. Na brunatno-fioletowym podłożu widoczna jest jaskrawo-pomarańczowa, niemal czerwona dwuskrzydłowa „rama okienna”. Drgający, pulsujacy kolor zarysu obwodu prostokata przywodzi na myśl płomienie, które ogarnęły ościeża okna, płomienie wydobywające się $z$ wypełnionego brunatnym dymem „wnętrza”, wydobywające się poza przestrzeń płótna. Tło obrazu - owa sugestia „wnętrza” - ma barwę żarzącego się zgliszcza, „wypełnionego” gęstym dymem koloru zaschniętej krwi. Wyobrażony zarys okna nie jest umieszczony centralnie, formy sa nieznacznie przesunięte tak, że percepcja dzieła wywołuje niepewność i niepokój, wzmocnione przygnębiająca „harmonią" rdzawych kolorów, które zdają się osaczać, sugerując pułapkę bez wyjścia. Murale do Seagram, zauważa Bonnie Clearwater, pozbawione sa sugestii miary, mogącej pomoc widzowi odzyskać utracone poczucie bezpieczeństwa, tak by mógł odna-

${ }^{20}$ Restaurację zdobiła kurtyna wykonana przez Pabla Picassa w 1919 r. do baletu Le Tricorne, do którego muzykę skomponował Manuel de Falla, twórca choreografii był Leonid Fyodorovich Myasin, Picasso zaprojektował także kostiumy, gobelin był dziełem Joana Mirò, rzeźba Richarda Lippolda oraz praca Jacksona Pollocka Blue Poles z 1952 r. 
leźć się w przestrzeni obrazu ${ }^{21}$. Niestabilna relacja między światłem a ciemnością, tym, co wewnątrz, i tym, co na zewnątrz płótna powoduje stan niepewności, a jednocześnie magnetycznego niemal pragnienia, by wejść w jego przestrzeń; pragnienia daremnego, nigdy niespełnionego. „Gdy wydaje się, że już wydostaliśmy się $z$ niej, spostrzegamy drzwi prowadzace do kolejnej otchłani. Niekończąca się podróż przez fryz obrazów powoduje uwięzienie widza w klaustrofobicznym labiryncie, z którego nie ma ucieczki, gdyż każda droga prowadzi ku drzwiom do kolejnej pułapki"22. W 1959 r. powstał Black on Maroon, kolejny, tym razem prostokątny $(228,5 \mathrm{~cm} \times 207 \mathrm{~cm})$ mural (dzieło obecnie znajduje się w zbiorach Tate Gallery w Londynie). Brunatne, posępne tło obrazu zostało pochłonięte przez czerń prostokąta, widoczne jest zaledwie przez dwa pionowe paski, dzielące przestrzeń płótna na trzy fragmenty oraz przy wąskich, rozmywających się krawędziach. Obcując $z$ tym dziełem, odczuwamy zakłócenie percepcji przestrzeni, towarzyszy nam niepewność, czy pionowe pasy zostały namalowane na czerni, czy też czerń „rozsunęła” się, by oddać nieco miejsca przebijającemu przez nią światłu? Kolejnym dziełem wykonanym do Four Seasons jest Red on Maroon - dramatyczny w wyrazie obraz o wyjątkowej sile emocjonalnej ${ }^{23}$. Wertykalnie skomponowane płótno ma ogromne rozmiary: $266,7 \mathrm{~cm}$ x 238,7 cm. Breslin kojarzy to dzieło $z$ malarskim wyobrażeniem portalu świątynnego, brama rytualnego przekraczania granicy sacrum i profanum. Zatrzymanie się u jej progu symbolizowało moment decyzji wyboru między wejściem a wyjściem, odejściem a powrotem, strata a odzyskaniem ${ }^{24}$. Brunatno-czerwone tło obrazu jest pokryte transparentna biela, widoczne jest na nim czerwone obrzeże prostokąta. Całość sprawia wrażenie uchylonych wrót, przez które niewyraźnie, jakby przysłonięta mgłą, szarym woalem albo dymem majaczy pusta przestrzeń,

${ }^{21}$ Por. B. Cle arwater, The Rothko Book, London 2006, s. 139.

${ }^{22}$ Ibidem.

${ }^{23}$ Wyjątkowo dramatyczny, $z$ premedytacją naruszajacy konwencje dzieł przeznaczonych do zdobienia wnętrz o charakterze rozrywkowym, wydźwięk tego cyklu obrazów Marka Rothki wskazuje, że artysta w procesie tworzenia swych monumentalnych płócien odchodził od zamierzonego przez zleceniodawców umieszczenia ich w sali restauracji Four Seasons. Świadomie, licząc się z odmową przyjęcia obrazów, pogłębiał skumulowany w nich tragizm, odniesienia do kwestii cierpienia i śmierci.

${ }^{24}$ Por. rzetelna i dociekliwa praca Agnieszki Przybyły, Mark Rothko i Four Seasons: murale do Seagram Building na Manhattanie, [praca magisterska napisana w Katedrze Historii Sztuki Uniwersytetu Łódzkiego pod kierunkiem E. Jedlińskiej], Łódź 2013, s. 59. 
otchłań ciszy i kontemplacji, może modlitwy za zmarłych. Rothko szczegółowo zaplanował sposób umieszczenia płócien - nisko, tuż nad podłoga w bliskiej odległości między sobą. Chciał, by otaczały widza, który stawał naprzeciw nich, jak staje się przed lustrem, na odległość kilkunastu centymetrów.

Wiosna 1960 r., krótko po tym, jak Rothko odmówił przekazania murali do Four Seasons, pracownię malarza odwiedził Werner Haftmann, niemiecki historyk sztuki i dyrektor Documenta w Kassel, by zaprosić artystę do prezentacji prac w Europie. Według Breslina Rothko odmówił Haftamannowi, uzasadniając swą decyzję niechęcią do masowych przeglądów sztuki, sugerując wystawienie obrazów w przestrzenni, która byłaby tylko im przeznaczona. $\mathrm{Na}$ propozycję kuratora, by dzieła Rothki zostały pokazane w specjalnie dla nich przeznaczonym pomieszczeniu, wedle jego wskazówek, artysta ponownie odmówił, wyjaśniając, że jako Żyd nie będzie wystawiał swoich prac w Niemczech, w kraju, gdzie narodził się faszyzm, w kraju, którego mieszkańcy dokonali tak wielkich zbrodni przeciwko jego narodowi. Słowa Rothki, przytoczone przez Breslina, brzmiały: "Jeżeli zbudujecie kaplicę i pokajacie się za Holocaust, to może być nawet namiot, namaluję wam coś za darmo"25.

Marzenie Rothki, by jego dzieła prezentowane były w specjalnie dla nich zbudowanym niewielkim sanktuarium, w którym obrazy będa kontemplowane w ciszy i skupieniu przez „strudzonego wędrowca" spragnionego modlitwy i spotkania $z$ wiecznościa, spełniło się w 1965 r. (realizacja została zakończona w 1966 r.). Wówczas powstała seria 14 obrazów namalowanych do kaplicy w Institute for Religion and Human Development (University of Saint-Thomas) w Houston ${ }^{26}$. Czternaście monumentalnych płócien, które w oktogonalnym wnętrzu skłaniaja subtelna gradacja ciemnych kolorów do metafizycznej kontemplacji, należy rozważać jako przesłanie wielkiego malarza-metafizyka. Rothko, dążąc do wydobycia czysto wizualnych, optycznych wartości obrazu pojmowanego jako płaszczyzna pokryta sugestywnymi barwami, tworzył dzieła pełne napięć, dramatyczne, domagające się od widza wdarcia

\footnotetext{
25 J.E.B. Breslin, op. cit., s. 407.

${ }^{26}$ Fundatorami kaplicy sa John i Dominique de Menil, kolekcjonerzy i mecenasi sztuki XX w. Kaplica stała się dominującym elementem architektonicznym i duchowym University of Saint-Thomas w Houston. Budowlę zaprojektował Philip Johnson, jeden $z$ najwybitniejszych architektów amerykańskich, ten sam, który zaproponował Rothce wykonanie murali do Seagram Building. Wnętrze zostało ukształtowane jako oktogon, ściśle wedle intencji malarza.
} 
w nie. W serii ogromnych Czarnych obrazów z Houston (największy obraz ma 4,50 m wysokości) osiagnął spokój, w którym widz, w samotności i religijnej niemal ciszy, może znaleźć absolutny stan skupienia i medytacji. Całość składa się z ośmiu obrazów, w tym trzy tryptyki, po jednym na każdą ścianę oktogonu, tworząc łącznie 14 paneli. Część obrazów pokryta jest pozornie jednobarwną farba, inne zawieraja starannie ograniczony na tle prostokat. Trzy jednolicie czarne panele tworzace trzy tryptyki umieszczone sa na trzech ścianach po zachodniej, północnej i wschodniej stronie kaplicy, wejście usytuowane jest po stronie południowej. Każdy $z$ obrazów ma status odrębnego dzieła, każdy przekazuje inne treści, łączy je wspólny dramat, a ich ostateczny przekaz zależny jest od intelektualnej i duchowej dyspozycji widza. Oktogonalny plan sprawił, że uczestnik tego misterium zostaje niejako „okrążony” przez dzieło, perspektywa wraz z krzywiznami kątów sprawia, że punkt widzenia skupiony na którymkolwiek $z$ paneli powoduje równoczesne ich widzenie i jednocześnie zbliżenie znajdujących się obok. Poszczególne obrazy usytuowane są w sposób, który całkowicie uniemożliwia ich samodzielne istnienie. Mroczna tonacja obrazów, ekstremalne zredukowanie kompozycji do czarnych prostokatów „wmalowanych” w czarne tło zdaje się zmuszać widza do metafizycznego powrotu do początku mitu jako źródła jaźni.

$$
* * *
$$

Dnia 6 sierpnia 1945 r. Barnett Newman w eseju zatytułowanym The New Sense of Fate, w odpowiedzi na wydarzenia drugiej wojny światowej, Holocaust i bomby zrzucone na Hiroszimę (6 sierpnia 1945 r.) i na Nagasaki (9 sierpnia 1945 r.), pisał: „Wojna, jak to przewidzieli surrealiści, wydarła $z$ nas utajone przerażenie, ponieważ może istnieć dopóty, dopóki pozostaja nieznane siły tragedii. Teraz wiemy, jak wygląda przerażenie. Pokazała nam je Hiroszima. Nie stoimy już wobec tajemnicy. A w końcu czyż nie dokonał tego amerykański chłopak? Przerażenie stało się w istocie równie realne jak życie"27.

W twórczości malarskiej Newmana odnajdziemy wiele odniesień do tematów i tytułów interpretowanych z perspektywy wiedzy kabalistycznej. Wpływy kultury żydowskiej na Newmana, podobnie jak

${ }^{27}$ B. N ew ma n, The New Sense of Fate..., http:/ /www.warholstars.org/abstract-expressionism/timeline/abstractexpressionism51.html (dostęp: 17 IV 2016 r.). 
na Marka Rothkę i Adolpha Gottlieba, są czytelne, a jego przepojona judajska tradycja mistyczną świadomość przerażenia wobec „niepoznawalnego" i niezgoda na wszechobecność gwałtu w świecie po Zagładzie znalazły swój szczególny wyraz w serii 14 stacji Drogi Krzyżowej. Temu dziełu poświęcam tę część tekstu.

Barnett Newman urodził się w Nowym Jorku w 1905 r. w żydowskiej rodzinie, w której kultywowane były tradycyjne święta i obyczaje. Jako najstarszy pośród trojga rodzeństwa odebrał edukacje obowiąująca chłopca uczęszczającego do chederu. Okres dzieciństwa spędzonego na Manhattanie wspominał jako szczęśliwe. Oboje rodzice, Anna i Abraham, wywodzili się z Łomży, do Ameryki przypłynęli w 1900 r. Jako 17-letni młodzieniec wiedział, że poświęci się sztuce, niebawem rozpoczał studia w nowojorskiej Art Student League, tej samej, do której uczęszczał Mark Rothko. Ich przyjaźń ugruntowały wspólne poglądy na sztukę, światopogląd, wspólne działania społeczne i polityczne. Obydwaj fascynowali się dramatami Ajschylosa i filozofia Nietzschego. W 1948 r. z Williamem Baziotesem i Robertem Motherwellem założyli akademię Subjects of the Artists.

Barnett Newman uważał, że siłą sprawcza aktu tworzenia sztuki było i jest przerażenie wobec „niepoznawalnego”. Owo przerażenie - uważał - jego ustawiczna obecność, wyznaczyło tragiczny los człowieka, świadomość beznadziejności i daremności wszelkiego działania, wobec „tragedii działania w chaosie, jakim jest społeczeństwo", stały się niejako ideologia ekspresjonizmu abstrakcyjnego, którego Newman był - obok Rothki, Gottlieba, Clyforda Stilla - czołowym przedstawicielem. Newman był głęboko przepojony wpływami żydowskich tradycji mistycznych, które wplecione w Nietzcheańska koncepcję życia jako tragedii, w konsekwencji afirmującej je przez sztukę, powołał tematy znaczące dla swego czasu, złączone $z$ problemami będącymi bezpośrednią reakcją na rzeczywistość, na konsekwencje dopiero co zakończonej wojny. Sztuka jedynie - głęboka i znacząca - może pomóc przezwyciężyć strach i zrozumieć brutalność świata naturalnego, jak i ustawicznej niepewności życia. Takie deklaracje wymagały tematu, który odpowiadałby na emocje i wyrażał ich głębię.

Wydarzenia drugiej wojny światowej widział Newman w kategoriach „moralnego załamania” sztuki: „malowanie kwiatów i grających na skrzypcach jest nonsensem" ${ }^{28}$. W latach 1940-1944 artysta

28 T.B. Hess, A Conversation. Barnett Newman and Thomas B. Hess, New York 1971; maszynopis tekstu Hessa - https://www.moma.org/momaorg/shared/ 
przestał malować, uznając nieadekwatność języka sztuki w obliczu poczucia dramatyzmu zdehumanizowanego świata współczesnej cywilizacji, w 1944 r. zniszczył wszystkie swoje prace $z$ wcześniejszego okresu. Pierwsze zachowane szkice i obrazy, pochodzace $z$ lat 1944-1946, noszace tytuły odnoszace się do archaicznych mitów (Zabójstwo Ozyrysa, Gea, Pieśn Orfeusza), abstrakcyjne, dramatyczne, malowane ostra, ekspresyjna plamą barwna, zdają się próba zmierzenia się $z$ tematem i kształtem, które przekraczałyby „nonsens obrazowania”, sięgnęłyby do idei dotykających misterium życia, człowieka i tajemnicy natury. W rzadkich na ten temat wypowiedziach Newmana wojna i Holocaust komentowane sa powściagliwie, formułowane lakonicznie i uogólniajacco. W jego komentarzach możemy dostrzec próby zrozumienia tych wydarzeń, wynikających z przekonania Newmana o niemożliwości powstrzymania ludzkiej skłonności do zła i przemocy. Taka postawa $z$ jednej strony wynikała $z$ tradycji żydowskiej, ale też $z$ głębokiej znajomości greckiej mitologii, wyznaczających ludzkiemu istnieniu bezradna zależność od sił irracjonalnych, na które człowiek nie ma wpływu, $z$ drugiej strony - braku odniesienia się do konkretnych historycznych korzeni, mających swój początek w ekonomii, polityce i ruchach społecznych. Rodowód totalitaryzmu jeszcze nie został zbadany. Mimo to Zagłada, zarówno dla Rothki, jak i dla Newmana, była wydarzeniem granicznym tak dla ich sztuki, dla ich światopoglądu, jak i dla całego świata zachodniego ${ }^{29}$.

W 1958 r. Barnett Newman rozpoczał pracę nad abstrakcyjnym cyklem Czternaście Stacji Drogi Krzyżowej. Lema Sabachthani, zakończonym w 1966 r. ${ }^{30}$ Dzieła te przechowywane sa w National Gallery w Waszyngtonie. Tak jak w przypadku poprzednich obrazów tak i w odniesieniu do Stacji tytuł cyklowi nadał artysta dopiero w trakcie pracy nad czwartym płótnem - wówczas - deklarował w rozmowie $z$ Davidem Sylvestrem - uświadomił sobie, że ich treścią jest Pasja Chrystusa, rozumiana jako samo doświadczenie agonii,

pdfs/docs/press_archives/4731/releases/MOMA_1971 (dostęp: 13 III 2016 r.); Ch. Harris o n, op. cit., s. 298-299.

${ }^{29}$ Por. B. New man, J.P. O'Neill, M. McNickle, R. Shiff, Selected Writings and Interviews, Berkeley-Los Angeles 1992: B. N ew man, Surrealism and the War, s. 95, http://www.warholstars.org/abstractexpressionism/timeline/abstractex pressionism1945b.html (dostęp: 13 III 2016 r.).

${ }^{30}$ L. Allow ay, Stations of the Cross and the Subjects of the Artist, [w:] Barnett Newman. The Stations of the Cross. Lema Sabachthani, katalog wystawy The Solomon R. Guggenheim Museum, New York 1966, s. 11-12. 


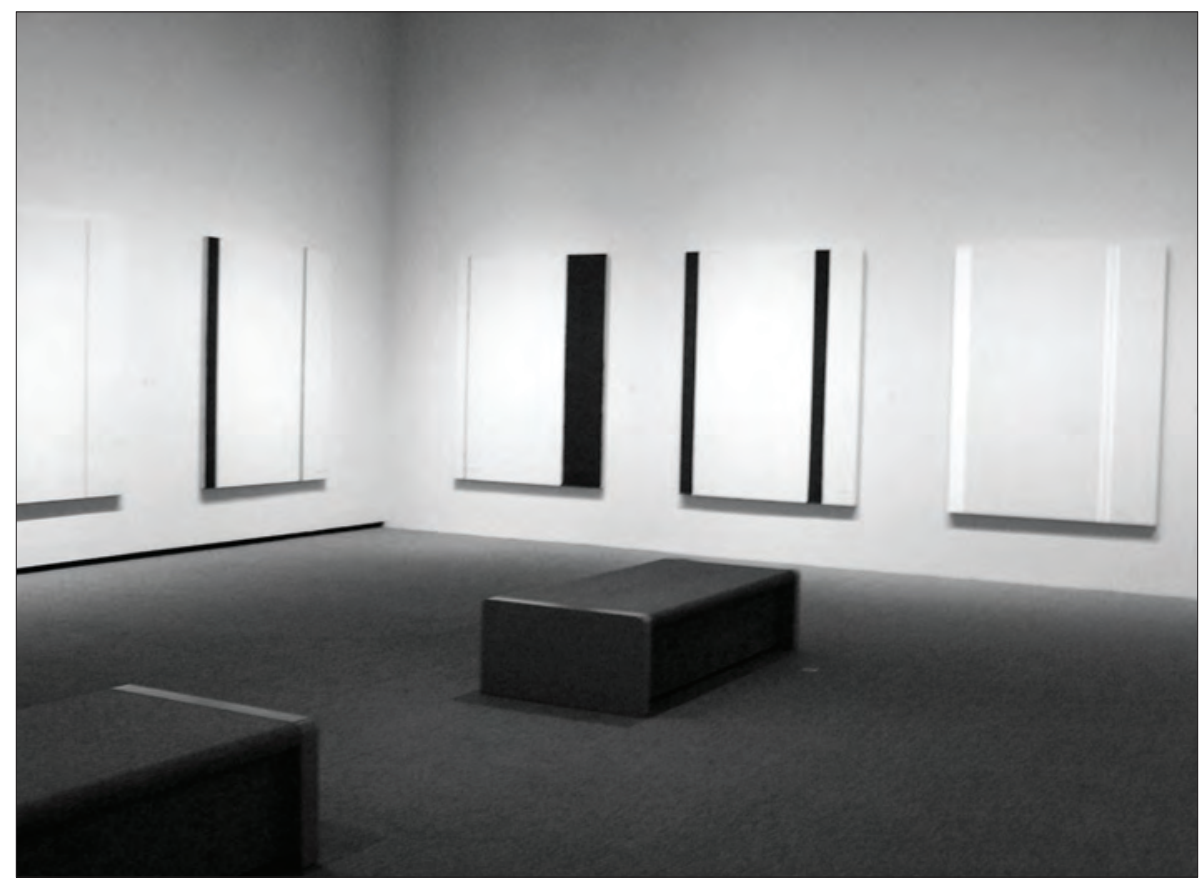

2. Barnett Newman, The Stations of the Cross: Lema Sabachthani, 1958-1966 r., National Gallery Waszyngton. Fot. E. Jedlińska

a nie szereg epizodów historii świętej ${ }^{31}$. Zazwyczaj swym obrazom Newman nadawał tytuły po ich ukończeniu, tytuł zatem nie opisywał tematu, był raczej przywołaniem określonych emocji, towarzyszacych ich powstawaniu i sugestia, że obraz znaczy ${ }^{32}$.

Mark Godfrey, autor książki Abstraction and the Holocaust, obrazy Newmana $z$ cyklu Czternaście Stacji Drogi Krzyżowej rozważa jako bezpośrednie odniesienie artysty do tematu Zagłady: „The Stations of the Cross is considered by many to be Newman's greatest achievement. It was his most ambitious attempt to address what he called a "moral crisis" facing artists after World War II and the Holocaust: What are we going to paint?"33. Abstrakcyjna

${ }^{31}$ Por. Interview with David Sylvester, [w:] B. N ew m a n, J.P. O’N ei11, M. M cNickle, R. Shiff, op. cit., s. 257.

${ }^{32}$ Ibidem, s. 258-259.

${ }^{33}$ M. Godfrey, Abstraction and the Holocaust, New Haven 2007. Godfrey w swej książce analizuje jako odnoszace się do tragedii Zagłady obrazy takich artystów, związanych $z$ abstrakcjonizmem i minimalizmem amerykańskim, jak m.in.: Moris Louis, Frank Stella, Barnett Newman, Mark Rothko, Richard Serra, 
forma, skrajnie zredukowane środki formalne owych 14 obrazów, z których każdy niejako wynika $z$ każdego, obrazów wyrażających bogactwo zawartości duchowych oraz ich odniesienie do treści liturgicznych sytuuja ten cykl dzieł Newmana w obszarze jego najdonioślejszych dokonań artystycznych i duchowych. Jest też owych 14 Stacji najważniejszym jego dziełem, które możemy rozpatrywać jako odnoszace się do tematu Holocaustu; proces sporządzania „wizerunków” znaczących Drogę Krzyżową Chrystusa trwał osiem lat $z$ przerwami, podczas których wykonywał inne prace. Tytuły kolejnych sekwencji (obrazów) nigdy nie sa tożsame $z$ obrazem - każdy skonstruowany jest na zasadzie wzajemnych relacji, nie opisuje tematu. Każde z płócien mierzy ok. $200 \mathrm{~cm}$ x $160 \mathrm{~cm}$. Niemal takie same, odpowiadajace proporcjom dorosłego człowieka, rozmiary obrazów, ich „rytmiczność” powoduje, że każde z tych płócien możemy traktować jako jedność, gdy patrzymy na nie $z$ daleka, a jednocześnie oglądane $z$ bliska wywołuja stan kontemplacji. Paleta jest ograniczona: czerń, biel, szarość i surowe płótno. Artysta użył farby olejnej oraz trzech różnych rodzajów farb syntetycznych; na powierzchni obrazów widnieja pozostałości taśmy, która naklejał, by oddzielić jeden pas farby od drugiego. Czerń $\mathrm{w}$ jednych obrazach jest oleista, dominujaca w innych nałożona bardzo cienka warstwą, niemal przezroczysta. W miejscach, gdzie użyta została gruba, ściekajaca warstwa farby olejnej, spływajacej jakby poza malowany obszar, poza miejsca zaklejone taśma, na surowym płótnie tworzą się żółte plamy. W jednych obrazach dominuje surowe płótno, przenikajace między pasami albo cieńszymi paskami, malowanymi czysta linia farby (Stacja Druga), w innych farba kładziona jest szerokim, gwałtowanym pociagnięciem pędzla (Stacja Pierwsza). Niektóre paski sa tak wąskie, jakby narysowano je ołówkiem, inne maja rozmyte, niewyraziste, jakby poszarpane brzegi. Cztery Białe Stacje sa $z$ dalekiej odległości niemal nieczytelne, pozbawione pierwszego planu, a ich „odległe” współistnienie, enigmatyczne światło skupiają wzrok, który szuka punktu oparcia. W 1966 r. Newman dołaczył do Czternastu Stacji obraz 15, który zatytułował Be II. Namalowany jest biała farba olejna, z lewej stro-

Joel Shapiro, Sol Lewitt i Elsworth Kelly. M. Godfrey, Barnett Newman's Stations and the Memory of the Holocaust, http://www.mitpressjournals.org/doi/ abs / 10.1162/016228704774115708?journalCode=octo\#.VuWdOJzhDcc (dostęp: 13 III 2016 r.). Por. także interpretacja rzeźb Shapiro, Lewitta i Kelly’ego w United States Holocaust Memorial Museum w Waszyngtonie: E. Jedlińska, Sztuka po Holocauście, Łódź 2001. 
ny widoczny jest kilkucentymetrowej szerokości pasek, wykonany wyraźnym pociągnięciem szkarłatu; po obu stronach płótna znajdują się proste pasy czerni. Ten obraz jest nieco większy w stosunku do pozostałych, formatem zbliżony do kwadratu ${ }^{34}$.

W katalogu wystawy Barnett Newman. The Stations of the Cross. Lema Sabachthani The Solomon R. Guggenheim Museum w Nowym Jorku w 1966 r. Barnett Newman pisał: "Lema Sabachthani-dlaczego? Dlaczegoś mnie opuścił? Jakie były Twoje zamiary? Dlaczego? To jest Męka Pańska. To jest głos protestu Chrystusa. Nie jest to straszna droga prowadzaca przez Via Dolorosa, ale pytanie, na które nie ma odpowiedzi. To przejmujące pytanie, które nie jest skarga, jest wyrazem naszego dzisiejszego osamotnienia. Na to pytanie nie ma odpowiedzi, ono jest $z$ nami od bardzo dawna - od czasu Jezusa - od czasu Abrahama - od czasu Adama - pierwsze pytanie. Lema? Po co? - pytanie bez odpowiedzi mówiące o ludzkim cierpieniu"35.

Umierający w samotności Chrystus wołający: „Dlaczego?” - według wykładni Newmana jest wcieleniem „agonii i cierpienia każdego człowieka: samotnej, nieustannej, nieubłaganej, nieuchronnej - świata bez końca"36.

Poszczególne obrazy Stacji Newmana nie łączą się z konkretnymi, zawartymi w Nowym Testamencie czy apokryfach opisami Pasji, czy wyobrażeniami wywiedzionymi $z$ historii sztuki, liczba $14^{37}$ została zdecydowana przez artystę i stanowi absolutna granicę i symbol ustanowiony przez malarza ${ }^{38}$. Jednakże porządek, w jaki

${ }^{34}$ Pierwotnie ten obraz pokazywany był osobno w Allan Stone Gallery, w 1962 r., wówczas Stone nazwał go Resurection, Newman jednak odrzucił ten tytuł. W roku 1964 nadał mu tytuł Be II i zdecydował o włączeniu dzieła w ramy Czternastu Stacji Drogi Krzyżowej.

${ }^{35}$ B. N ew m a n, Statement, [w:] Barnett Newman. The Stations of the Cross..., s. 9.

${ }^{36}$ V. Hells tein, Barnett Newman, The Stations of the Cross: Lema Sabachtani, „Object Narrative. In Conversations: An Online Journal of the Center for the Study of Material and Visual Cultures of Religion", http://mavcor.yale.edu/conversations/object-narratives/barnett-newman-st (dostęp: 13 IV 2016 r.).

37 Symbolika liczby 14 w gematrii łączy się z królem Dawidem: w języku hebrajskim cyfry zapisywano literami, w słowach opuszczano samogłoski (np. DAWID: $\mathrm{D}+\mathrm{W}+\mathrm{D}=4+6+4=14)$. Liczba 7 symbolizuje doskonałość i świętość. Podwojona liczba 7 - 14 symbolizuje dobroć i miłosierdzie. Na temat kabalistycznych zainteresowań Newmana pisał T.B. Hes s, Barnett Newman, New York 1971, s. 56.

38 Temat Stacji Drogi Krzyżowej jest zjawiskiem ikonograficznym ustanowionym dość późno w obrazowaniu chrześcijańskim. Dopiero w XVII w. ten temat rozwiną się w formie nowożytnej, jako rozwinięcie pierwotnie znacznie krótszego tematu. Od XV w. spotykamy liczne przedstawienia Drogi Krzyżowej w formie scen 
układaja się te obrazy, odzwierciedla chronologia ich powstawania (między 1958 r. a 1962 r. namalował Stacje Pierwsza, Druga, Trzecia i Czwarta, w 1962 r. Stacje Piąta i Szósta, w 1964 r. Stacje Siódma, Ósma i Dziewiata, w 1965 r. powstały Stacja Dziesiata, Jedenasta i Dwunasta, Stacje Trzynasta i Czternasta zaczą malować w połowie 1965 r. i ukończył w 1966 r.). Temat zatem jest tu nie tylko źródłem dociekań teologicznych Newmana, lecz także powinniśmy pojmować go jako równoległy $z$ życiem artysty - obrazy poprzedzajace cykl - twierdzi Alloway - sa jego zapowiedzią: „[...] maja się do siebie jak proroctwa w Starym Testamencie do ich spełnienia w Nowym Testamencie"39. Newman podkreślał, że Czternaście Stacji Drogi Krzyżowej należy widzieć jako kolejne fazy ustawicznej agonii Jezusa, nie zaś jako serię oddzielnych epizodów. $Z$ tej perspektywy jego koncepcja wyobrażenia Pasji pozostaje $\mathrm{w}$ zgodzie $z$ tradycyjna ikonografią. Jedna $z$ konsekwencji tego poglądu jest dodanie 15 obrazu zatytułowanego Be II, który ma inne rozmiary i inne barwy; jednolicie białe pole flankowane jest pasami oranżu i czerni. To płótno jest łącznikiem między krzyżem a lamentem człowieka, między Chrystusem Człowiekiem a Chrystusem Bogiem. W tytule cyklu zawarte sa Ostatnie Słowa Chrystusa na Krzyżu, słowa wypowiadane przez człowieka: „Boże Mój, Boże, czemuś mnie opuścił / Czemu nas opuściłeś?”. Decyzja dodania tych słów podyktowana była podkreśleniem jedności Męki Chrystusa $z$ momentem Jego śmierci jako apogeum. Obraz Be II nie tyle łaczy owych 14 Stacji Drogi Krzyżowej, co sytuuje się ponad nimi jako ostatnie PYTANIE-KRZYK skierowane do Ojca. Abstrakcyjna forma Czternastu Stacji Drogi Krzyżowej sprawia, że ból i cierpienie Jezusa zyskuja uniwersalny wymiar, Jego samotność i opuszczenie w chwili śmierci staje się doświadczeniem człowieka każdej religii i każdego czasu.

$$
* * *
$$

Frank Stella, najmłodszy $z$ trójki prezentowanych tu artystów, należy już do drugiego pokolenia malarzy abstrakcji geometrycznej w Ameryce. Jest pośród nich jedynym, który nie jest Żydem, i jedynym, którego radykalnie abstrakcyjne obrazy nosza tytuły bezpo-

przedstawiajacych siedem Upadków Chrystusa - 7 jako liczba święta, wyprowadzona $z$ ogólnego opisu wydarzeń w Ewangelii św. Łukasza.

${ }^{39}$ L. Alloway, op. cit., s. 13. 
średnio odnoszące się do czasu faszyzmu i Holocaustu (Reichstag z 1958 r., obraz, którego konstrukcja jest - wedle interpretacji Anne C. Chave - odległym echem planu budowli ${ }^{40}$, Die Fahne hoch z 1959 r. oraz z serii Black Paintings $I^{41}$ obraz Arbeit macht Frei z 1958 r.). Stella urodził się w Stanach Zjednoczonych w 1936 r., studiował w Princeton. Seria jego minimalistycznych, „eleganckich, acz drastycznych" Czarnych obrazów powstała w najwcześniejszym okresie twórczości artysty. Krytyka zaintrygowana była „arbitralna, irracjonalna geometria" ${ }^{42}$ formujaca jego obrazy, malowane nowymi rodzajami pigmentów, rozpuszczalnymi w wodzie, wytwarzanymi na bazie plastyku. Stosowanie owych bardzo błyszczacych farb o właściwościach fluorescencyjnych oraz metalicznych pigmentów odbijających światło zdecydowały o wyodrębnieniu malarstwa amerykańskich abstrakcjonistów pokolenia lat sześćdziesiątych od wcześniejszych stylów geometrycznych, zauważa Barbara Rose ${ }^{43}$. W serii czarnych płócien sieć czarnych linii raz jest równoległa do krawędzi obrazu, innym razem jest ukośna albo skomponowana $z$ połączenia obu układów. Pasy farby maja zawsze jednakową szerokość, zachowany został ślad gestu pędzla, niekiedy ledwie dostrzegalny, uwidaczniajacy proces powstawania dzieła. Niekiedy paski prześwitującego płótna są niemal niewidoczne, w niektórych miejscach płótno sprawia wrażenie monochromatycznego.

Skupmy uwage na obrazie, którego interpretacja zawarta jest $\mathrm{w}$ tytule nadanym mu przez artystę i jednocześnie sugeruje analizę. Anne C. Chave przywołuje wypowiedź Franka Stelli, który opisujac obraz Arbeit macht Frei, stosował takie słowa, jak: siła, strach, nadzorować, konfrontacja. Obmyślając ten obraz, artysta zamierzał, by oddziaływanie dzieła było uderzajace, jednoznacznie „bijace po oczach” („direct-right to your eye”). Osiagnął zamierzony efekt przez zbudowanie iluzjonistycznej przestrzeni wyznaczonej niewielkimi odstępami między poszczególnymi paskami, tworząc regularny, obsesyjny wzór. Docentryczny rytm białych i czarnych pasków „zamknięty” jest organizującym przestrzeń skrzyżowaniem linii poziomej i pionowej, wyznaczajacych antyczny schemat obozu

${ }^{40}$ A.C. Chave, Minimalism and the Rhetoric of Power, s. 119, https://www.msu. edu/course/ha/452/chaverhetoric.pdf (dostęp: 18 III 2016 r.).

${ }^{41} \mathrm{~W}$ poczatkach lat sześćdziesiątych Stella realizuje cykl Czarnych obrazów, składajacy się z 23 prac, uznanych za pierwszy manifest minimalizmu.

${ }^{42}$ Ibidem; A.C. Chave, Minimalism and the Rhetoric of Power..., s. 119.

${ }^{43}$ B. Ros e, Malarstwo amerykańskie dwudziestego wieku, przekł. H. Andrzejewska, Warszawa 1991, s. 98. 


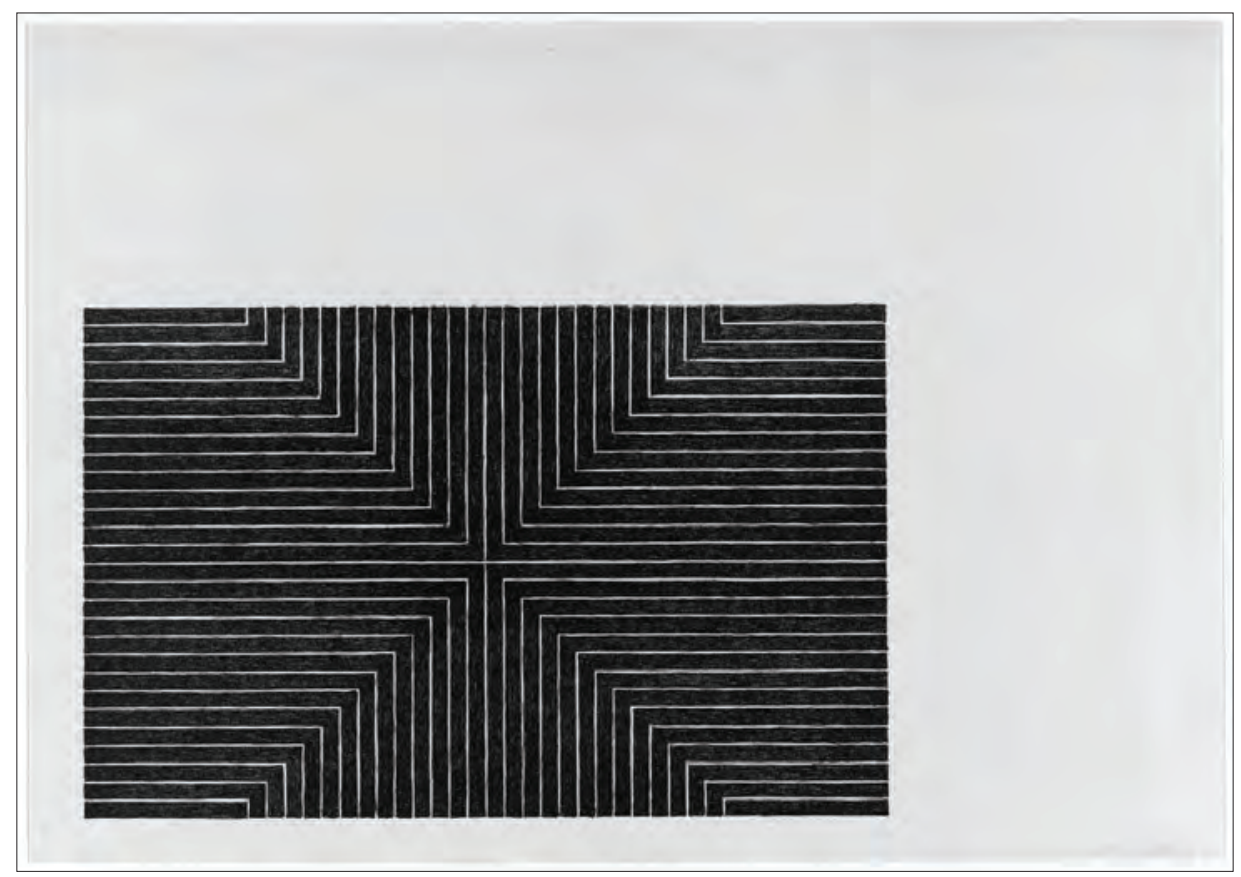

3. Frank Stella, Arbeit macht frei (z Czarnej serii), 39 x 55,4 cm, 1967 r., Museum of Modern Art, Nowy Jork. Fot. E. Jedlińska

rzymskiego albo planów rzymskich miast zakładanych według ściśle opracowanego wzorca. Opresyjny rytm linii i pasków prowadzących do centrum obrazu zdaje się zamykać możliwość wyjścia poza ów obszar, działa niczym rozpadlina niwelująca wszelkie życie, dziejące się poza nim. Calvin Tomkins przywołuje słowa Stelli w czasie, gdy artysta rozpoczał prace nad cyklem Czarnych obrazów, w których konfrontuje on własne odczucia związane $z$ niemożliwością obrazowania doświadczenia Zagłady i przekonanie, że chciał, by „obraz, jaki wytworzył w sobie, został zatrzymany i opanowany” („I wanted to hold it down and establish control") ${ }^{44}$. Owa decyzja zatrzymania i opanowania minimalistycznej, rygorystycznej formy, ustanawia - uważa Tomkins - centralny problem Czarnych obrazów, taka perspektywa interpretacyjna szczególnie odnosi się do pierwszego dzieła tego cyklu (Arbeit macht Frei z 1958 r.) oraz do obrazu Die Fahne hoch!, namalowanego kilka miesięcy później. Drugi obraz jest właściwie formalnym powtórzeniem pierwszego, jedynie horys. 63.

${ }^{44}$ C. Tomkins, The Space Around Real Things, „The New Yorker”, 10 IX 1984, 
zontalny układ został tu odwrócony na pionowy. Dłuższe krawędzie maja identyczne wymiary, krótsze w przypadku Die Fahne hoch! sa o $30 \mathrm{~cm}$ mniejsze. Podczas gdy obraz zatytułowany Arbeit macht Frei odnosi się do napisu na bramie prowadzacej do obozu Auschwitz, tytuł drugiego to pierwsze słowa pieśni, której autorem był Horst Ludwig Wessel, niemiecki nazista, członek SA-Sturmführer ${ }^{45}$.

W konsekwencji namalowania tych dwóch obrazów, w 1960 r. powstały szkice, opatrzone notatkami Stelli oraz studiami różnych form w kształcie krzyża, będacego podstawą dzieł. Poniżej widoczny jest napis: „the final solutin”. Brenda Richardson interpretuje ten napis jako wiążący dla interpretacji omawianych tu dwóch obrazów, a forma krzyża miałaby być odniesieniem do Ukrzyżowania Chrystusa, do znaczącej obecności Jezusa w ikonografii artystów żydowskich, ale także do szczególnego procesu myśli twórcy dokonującego niejako mentalnego zrównania krzyża jako znaku bólu, cierpienia, śmierci, ale też jako emblematu używanego przez nazistów $^{46}$. W początkowym zamyśle - zauważa Cheve - artysta chciał

${ }^{45}$ Horst Ludwig Wessel, niemiecki nazista, członek SA-Sturmführer. Wessel był uzdolniony muzycznie. Grał na oboju, założył kapelę SA, która grała podczas parad i spotkań SA i przyciagała nowych zwolenników. Na początku 1929 r. gazeta NSDAP „Der Angriff”, wydawana przez Josepha Goebbelsa, opublikowała wiersz Wessela pt. Der Unbekannte SA-Mann, który później z ludową melodia znany był jako Horst-Wessel-Lied. W roku 1930 w Berlinie Wessel został zastrzelony przez członka organizacji komunistycznej (RFB - Roter Frontkämpferbund), prawdopodobnie chodziło o prywatne porachunki. Po śmierci Wessela Goebbels, szef nazistowskiej propagandy, ogłosił go męczennikiem za narodowy socjalizm. Urządzono uroczysty pogrzeb, przerwany przez komunistów, którzy zaatakowali procesję kamieniami. Podczas ceremonii pierwszy raz publicznie odśpiewano Horst-Wessel-Lied. W pogrzebie wzięło udział 30000 ludzi. Naziści jeszcze przed dojściem do władzy uczynili z Wessela swego męczennika i wykorzystali go do celów propagandowych. Stał się bohaterem SA. Pieśń Die Fahne hoch była, zaraz po oficjalnym hymnie Deutschland, Deutschland über alles, najczęściej śpiewana pieśnia na uroczystościach państwowych. Po przejęciu władzy przez nazistów dzielnica Berlina Friedrichshain została przemianowana na „Horst-Wessel-Stadt” i nosiła tę nazwę do 1945 r. Szpital, w którym zmarł Wessel, został również nazwany jego imieniem. Bülowplatz w Berlinie, tamtejsza stacja metra, 18. ochotnicza dywizja grenadierów pancernych Waffen-SS, szkoły i wiele innych instytucji zostało przemianowanych na cześć Wessela. Hanns Heinz Ewers napisał powieść Horst Wessel, wydana w Stuttgarcie w 1932 r. Nazwiskiem Wessela nazwano także trójmasztowy bark, który został zbudowany w 1936 r. w Hamburgu jako szkolny okręt Niemieckiej Marynarki Wojennej. Po II wojnie światowej statek przejęła Marynarka Wojenna Stanów Zjednoczonych, pod bandera której pływa on nadal pod nazwa „Eagle”, https://pl.wikipedia.org/wiki/Horst_W (dostęp: 20 III 2016 r.).

${ }^{46}$ B. Rich ards o n, Frank Stella: The Black Paintings, Baltimore 1976, s. 12. 
zatytułować obraz Arbeit macht Frei angielskim tytułem The Sacred Heart, ale ostatecznie zdecydował uniknąc w tytule odniesień religijnych czy politycznych ${ }^{47}$. Tylko dwa z 23 obrazów cyklu Black Painting maja tytuły, które moga być rozpoznawane jako polityczne: Arbeit macht Frei i Reichstag. Krytykowany za dwuznaczność interpretacyjna obrazów, które moga przez tytuły odnosić się do Holocaustu bądź przez formę (np. krzyża maltańskiego) odwoływać się do emblematów faszystowskich, Stella prowokacyjnie replikował, mówiąc o „doskonałych proporcjach kształtu swastyki”, które chciał wykorzystać w swoich obrazach ${ }^{48}$. Niejednoznaczność wypowiedzi artysty, tytuły, jakie nadaje obrazom, jego słynna deklaracja: "What you see is what you see” czy też: „The title seems to me the way the painting looks" pozwalaja widzieć tę postawę twórcza jako dystansujacca się od narzucanych - wobec tematu Holocaustu - stereotypów wyobrażeniowych.

$$
* * *
$$

Abstrakcyjna forma dzieł Rothki, Newmana i Stelli - trzech amerykańskich artystów, których wybrane przykłady przywołałam - jakkolwiek pozbawione jednoznacznego odwołania do Holocaustu, odrzucenie tradycyjnych form obrazowania, przez swa ekspresyjna powściagliwość „wypełniają" owa pustkę metafor, o której pisała Doreet Le Vitte-Harten, wobec „zakazanej” sakralizacji Holocaustu $^{49}$. Dzieła te nie ilustruja doświadczeń Holocaustu, odniesienie do Zagłady nie jest ich wewnętrzną treścią, sa oczyszczone $z$ rzeczywistości, pozostając jej symbolem ${ }^{50}$. Nadawane tym dziełom sugestywne tytuły wydaja się jedynymi wskazówkami interpretacyjnymi, to odbiorca jest odpowiedzialny, przed samym soba, za to, co zobaczył i co zrozumiał: „Widzisz to, co widzisz” - mówił Stella. Obrazy Franka Stelli nie sa poematami (słowa Theodora W. Adorna o niestosowności istnienia poezji po Zagładzie w Czarnych obrazach Marka Rotki i 23 Czarnych obrazach Stelli zdają się wypełniać deklarację filozofa), czarne pasy i cienkie białe linie wyglądaja jak puste miejsca po słowach, które kiedyś były, których wówczas, kilkanaście lat po II wojnie światowej, nie sposób było wyartykuło-

\footnotetext{
47 A.C. Chave, Minimalism and the Rhetoric of Power..., s. 119.

48 Ibidem, s. 123.

49 Por. D. LeVitte Harten, op. cit., s. 18.

50 Por. E. Jedlińska, op. cit., s. 186.
} 
wać, bo, mówiąc słowami Samuela Becketta: „nie ma nic do wyrażenia, nie ma czego wyrażać, nie ma komu wyrażać, nie ma sił by wyrażać, nie ma chęci wyrażania, ani obowiązku by wyrażać" ${ }^{51}$.

\section{Bibliografia}

\section{OpRacowania}

Alloway L., Stations of the Cross and the Subjects of the Artist, [w:] Barnett Newman. The Stations of the Cross. Lema Sabachthani, katalog wystawy The Solomon R. Guggenheim Museum, New York 1966.

Amishai M.Z., Depiction and Interpretation: The Influence of the Holocaust on the Visual Arts, Oxford 1993.

Ashton D., About Rothko, New York 1996.

Bartelik M., Na zewnatrz widzenia. Lekcje Marca Rothki, [w:] Mark Rothko. Obrazy $z$ National Gallery of Art w Waszyngtonie, red. M. Bartelik, katalog wystawy Muzeum Narodowe w Warszawie, Warszawa 2013.

Beckett S., Trzy dialogi z Georges'em Duthuit, [w:] Samuel Beckett. Esej. Wierność przegranej, przekł. A. Libera, M. Nowoszewski, Kraków 1999, s. 51-62.

Breslin E.B.J., Mark Rothko. A Biography, Chicago 1989.

Chave C.A., Mark Rothko. Subjects in Abstraction, New Haven 1989.

Clearwater B., The Rothko Book, London 2006.

Godfrey M., Abstraction and the Holocaust, New Haven 2007.

Harrison Ch., Ekspresjonizm abstrakcyjny, przekł. H. Andrzejewska, [w:] Kierunki i tendencje sztuki nowoczesnej, Warszawa 1980.

Hess B.T., Barnett Newman, New York 1971.

Jedlińska E., Sztuka po Holocauście, Łódź 2001.

Kleeblatt L.N., Tragedia u Macy'ego. Rothko i mit, przekł. M. Lavergne, [w:] Mark Rothko. Obrazy z National Gallery of Art w Waszyngtonie, red. M. Bartelik, katalog wystawy Muzeum Narodowe w Warszawie, Warszawa 2013.

LeVitte H.D., Przekładanie bólu na kolor, przekł. D. Kozińska, [w:] Gdzie jest brat Twój, Abel?, katalog wystawy Galerii Zachęta w Warszawie, Warszawa 1995.

Mark Rothko. Writings on Art, ed. M. Lopéz-Remiro, New Haven-London 2006.

Newman B., The Stations of the Cross. Lema Sabachthani, New York 1966.

Newman B., O'Neill J.P., McNickle M., Shiff R., Selected Writings and Interviews, Berkeley-Los Angeles 1992.

Pappas A.P., Mark Rothko and the Politics of Jewish Identity, 1939-1945, Los Angeles 1997.

${ }^{51}$ S. Beckett, Trzy dialogi z Georges'em Duthuit, [w:] Samuel Beckett. Esej. Wierność przegranej, przekł. A. Libera, M. Nowoszewski, Kraków 1999, s. 51-62. 
Przybyła A., Mark Rothko i Four Seasons: murale do Seagram Building na Manhattanie, [praca magisterska napisana w Katedrze Historii Sztuki Uniwersytetu Łódzkiego pod kierunkiem E. Jedlińskiej], Łódź 2014.

Richardson B., Frank Stella: The Black Paintings, Baltimore 1976.

Rose B., Malarstwo amerykańskie dwudziestego wieku, przekł. H. Andrzejewska, Warszawa 1991.

Rosenblum R., Modern Painting and the Northern Romantic Tradition. Friedrich to Rothko, New York 1975.

Rothko Ch., Mark Rothko i muzyka, przekł. M. Lavergne, [w:] Mark Rothko. Obrazy $z$ National Gallery of Art $w$ Waszyngtonie, red. M. Bartelik, katalog wystawy Muzeum Narodowe w Warszawie, Warszawa 2013.

Rothko M., The Artist's Reality. Philosophies of Art, ed. C. Rothko, New Haven-London 2004.

Stoller E., Schulze F., The Seagram Building, Princeton 1999.

Tomkins C., The Space Around Real Things, „The New Yorker”, 10 IX 1984.

\section{Netografia}

Chave C.A., Minimalism and the Rhetoric of Power, https://www.msu.edu/course/ ha/452/chaverhetoric.pdf (dostęp: 18 III 2016 r.).

Friedman B.H. (B.H.), The Most Expensive Restaurant Ever Built, „Evergreen Review" 1959, No. 10, http://www.evergreenreview.com/120/friedman.html (dostęp: 12 III 2016 r.).

Hellstein V., Barnett Newman, The Stations of the Cross: Lema Sabachtani, „Object Narrative. In Conversations: An Online Journal of the Center for the Study of Material and Visual Cultures of Religion", http://mavcor.yale.edu/conver sations/object-narratives/barnett-newman-st (dostęp: 13 IV 2016 r.).

Hess B.T., A Conversation. Barnett Newman and Thomas B. Hess, New York 1971; maszynopis tekstu Hessa - https://www.moma.org/momaorg/shared/pdfs/ docs/press_archives/4731/releases/MOMA_1971 (dostęp: 13 III 2016 r.).

Newman B., The New Sense of Fate, http:/ /www.warholstars.org/abstractexpre ssionism/timeline/abstractexpressionism51.html (dostęp: 17 IV 2016 r.).

Newman B., Surrealism and the War, http://www.warholstars.org/abstractexpre ssionism/timeline/abstractexpressionism1945b.html (dostęp: 13 III 2016 r.).

https://pl.wikipedia.org/wiki/Horst_W (dostęp: 20 III 2016 r.). 


\title{
The painting is a testimony of the inconceivable Abstract Expressionism and the Shoah (Mark Rothko, Barnett Newman, Frank Stella)
}

\begin{abstract}
$T$ he history of Europe of 1933-1945 was very important and had a significant influence on painting of American artists of American abstractionism. This term - American abstractionism or New York abstractionism, although inexact and somewhat confused, currently is a constant term in the terminology of history of art. Taking this kind of art into consideration from the time between 1933 and 1945, recalling the special titles of art works and the context when they were created: Mark Rhotko's numbered, gray, brown and black murals which he painted for Manhattans Seagram Building in the fifties or his black and brown pictures for Huston Chapel in Texas form the seventies as well as Barnet Newmen's fourteen canvas titles The Stations of the Cross: Lema Sabachthani and Frank Stella's minimalist canvas titles Arbeit macht frei (1958), The Polish Village Series and the cycle of twenty four paintings which he created in his adolescence time, considering their comments and biography we have to understand this art as the historical art. These three artists of American expressionism - Mark Rothko, Barnett Newman and Frank Stella, whom this article is devoted to - refer in some pictures to the catastrophe of Shoah. They give evidence of this cruel time by the image, ostensibly without formal coincidence, they attempt to express unimaginable. They want, to some extent, to force us to imagine what the hell of Shoah was like.
\end{abstract}

Keywords: paintings, American Expressionism, abstraction, philosophy, testimony, Mark Rothko, Barnett Newman, Frank Stella, Shoah. 